\title{
Experimental study on bearing characteristc of Passive pile under soil lateral settlement
}

\author{
YANG Q ingguang1, a, Wang Guofeng ${ }^{1, b}$,XIE Song $1, c$ \\ ${ }^{1}$ College of Civil Engineering,Hunan University of Technology,Zhuzhou,Hunan 412007,China \\ ayqg1210@126.com, ${ }^{\mathrm{b}}$ 864821396@qq.com, ${ }^{\mathrm{c}}$ 736414468@qq.com,
}

\begin{abstract}
Keywords: soil lateral displacement ,pipe pile,vertical bearing capacity
Abstract. In order to study the effect of lateral soil movement on the bearing behavior of the pipe pile, the six pipe piles under different lateral soil movement and different lateral movement position have been tested in lab. The displacement of pile top for the lateral displacement of the soil, the soil pressure around the pile and the settlement of the pile during the vertical loading are measured. The results show that the soil around pile is mainly compacted or plastic flow around piles in the process of soil lateral migration. The effect of the lateral displacement of the soil is the most significant on the position of 2 times pile diameter.The vertical bearing capacity of the pipe pile can been increased by effect of soil compaction, and the pile settlement can been decreased by the plastic flow around the pile. Due to the lateral displacement of the soil, and the proportion of the load is increased by the tension in the middle of the pile.
\end{abstract}

\section{Introduction}

For the reason of high bearing capacity,low cost,high quality piling,et.al.pipe pile has been wildly applied in soft ground engineering. However,the lateral settlement for load on the ground,tunnel excavation and piling,the pile bears lateral positive load which has been entitled positive pile by De Beer[1].There are many analysis method for passive pile-soil interaction,such as experience method, displacement method and soil pressure method [2,3].The bearing characteristic of pile foundation for lateral displacement of soil had been studied by Franx [4].By model test, large passive soil pressure which leads to unstability of pile has been founded by Franx. Soil arching effect has been founded and validated by K.Terzaghi[5].M oreover,Simplified calculation model for bearing capacity of passive pile has been developed by Yan Reng-jue and Li Zhong-cheng[6] 。 In this paper, to reveale relationship of lateral displacement of soil and vertical bearing capacity of pile, a model test had been conducted by changing lateral displacement of soil and load position.

\section{Summary of model test}

Test equipment. The test maked in a foundation pit of $6.0 \mathrm{~m} \times 3.0 \mathrm{~m} \times 4.0 \mathrm{~m}$ includes six pipe piles. The internal diameter is $400 \mathrm{~mm}$ and external diameter is $700 \mathrm{~mm}$. The settlement of soil and load position is shown as Fig.1.Moreove,soil pressure beside pile is measured by soil pressure cell.The lateral displacement of soil and settlement can been achieved by dialgages, as shown in figue 1 . 


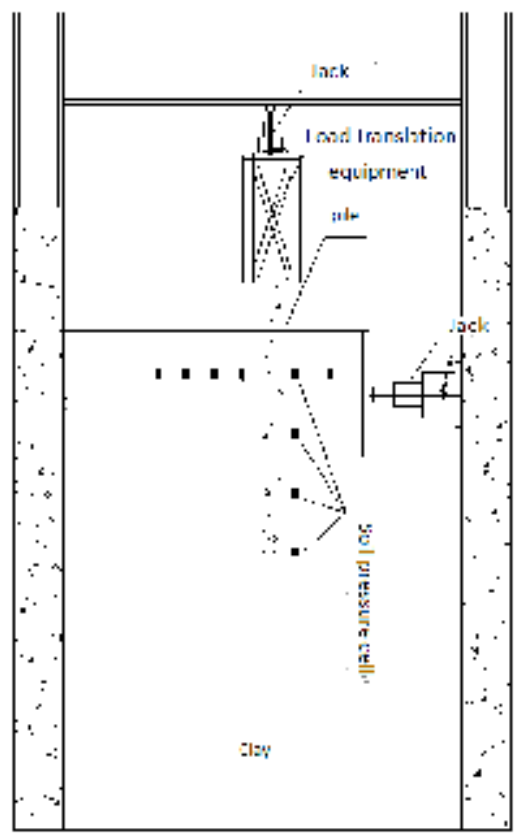

Fig 1 Test equipment

Soil Preparation.The soil of test is caly gotten from an excavation of zhuzhou city.It is air-dried and sized.It is filled in layers to foundation and is maintained two monthed at least.The water content is $22.3 \%$, cohense is $16.8 \mathrm{kPa}$, the internal friction angle is $19.8^{\circ}$ and density is $1.90 \mathrm{~g} / \mathrm{cm} 3$.

Tab.1 Settlement of soil and load position

\begin{tabular}{|c|c|c|c|c|c|c|}
\hline Num of pile & $1 \#$ & $2 \#$ & $3 \#$ & $4 \#$ & $5 \#$ & $6 \#$ \\
\hline $\begin{array}{c}\text { Lateral displacement } \\
\text { of soil }\end{array}$ & 0 & $0.5 \mathrm{~d}$ & $1 \mathrm{~d}$ & $1.5 \mathrm{~d}$ & $1 \mathrm{~d}$ & $1 \mathrm{~d}$ \\
\hline Load position & $/$ & \multicolumn{3}{|c|}{$6 \mathrm{~d}$} & $4 \mathrm{~d}$ & $8 \mathrm{~d}$ \\
\hline
\end{tabular}

\section{Analyzing Results of Experiment}

The analysis of soil lateral displacement and pile top settlement. The curve is shown as Fig.2.According to Fig.2,it can been found that pile will raise when there is soil laternal dispalcement.The uplift volumn of pile top will decrease with the improvement of pile centre distance.It can also been found that the pile will sink with the improvement continuelly. The maximum uplift volumns are $4.5 \mathrm{~cm}, 5.0 \mathrm{~cm}, 3.0 \mathrm{~cm}$ respectively to pile $5 \#, 3 \#$ and $6 \#$.

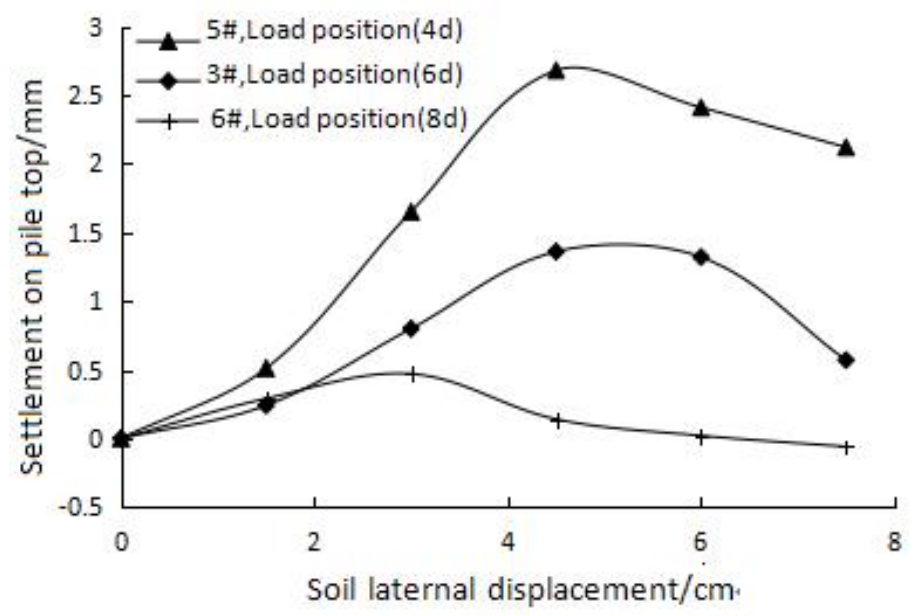

Fig 2 curve of soil lateral displacement and pile top settlement

Soil lateral displacement and pressure. The curve is shown as Fig.3.According to Fig.3, it can been found that there is a obvious has an obvious turning point and the soil pressure closes to zero 
on the bottom of pile.Moreover,the soil pressure before pile increases with the improvement of laternal displacement on the position of 0.6

times pile diameter.Howerer, when the laternal displacement increases continuely,the soil pressure will not change ouviously.

The soil pressure curve is shown as Fig.4.According to Fig.4,soil pressure increases firstly and then decrease with the improvement of soil laternal dispalcement on the position 4d.Moreover,it can been see that the increment speeds of soil pressure have obvious different for distance between measure point to pile centre.
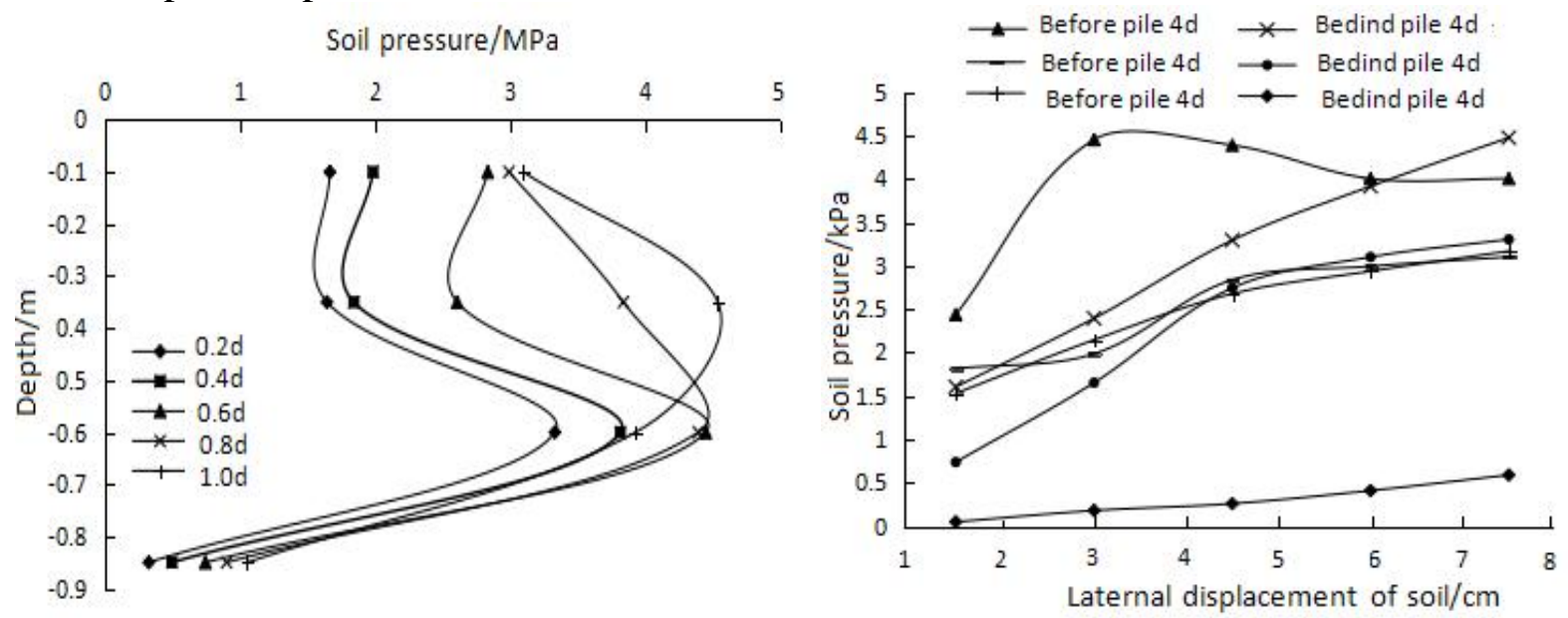

Fig. 3 Curve of soil pressure before pile Fig.4 curve of soil pressure on side of pile

Relationship of load-settlement. The curve is shown as Fig.5(a).According to fig.5(a),it can been found that load-settlement curve of pile $1 \#$ has a obvious turning point.However,the curve of other piles have not obvious turning point for the reason of soil laternal displacement.The vertical settlement of pile without laternal soil displacement is lower than pile with laternal soil displacement.The veritical settlements are $1.64 \mathrm{~mm}, 2.72 \mathrm{~mm}, 3.34 \mathrm{~mm}$ and $6.37 \mathrm{~mm}$ to pile $1 \#$ 、2\#、 $3 \# 、 4 \#$ respectively when the veritical load is $4 \mathrm{kN}$. The dettlements improve $65.9 \%, 102.4 \%$ and $288.4 \%$ respectively comparing with pile 1\#.Moreover,according to technical code for building pile foundations (JGJ94-2008) of china, the ultimate bearing capacities are $4.68 \mathrm{kN}, 4.05 \mathrm{kN}, 3.86 \mathrm{kN}$ respectively to pile $2 \# 、 3 \#$ and $4 \#$. According to fig.5(b), the ultimate bearing capacity of pile $5 \#$ is $6.5 \mathrm{kN}$ and the vertical settlement is $3.73 \mathrm{~mm}$ on the position of 4 times pile diameter distance.Moreover, the ultimate bearing capacity of pile $6 \#$ is $5.5 \mathrm{kN}$ on the position of 8 times pile diameter distance which has $22.2 \%$ increase than pile $1 \#$.

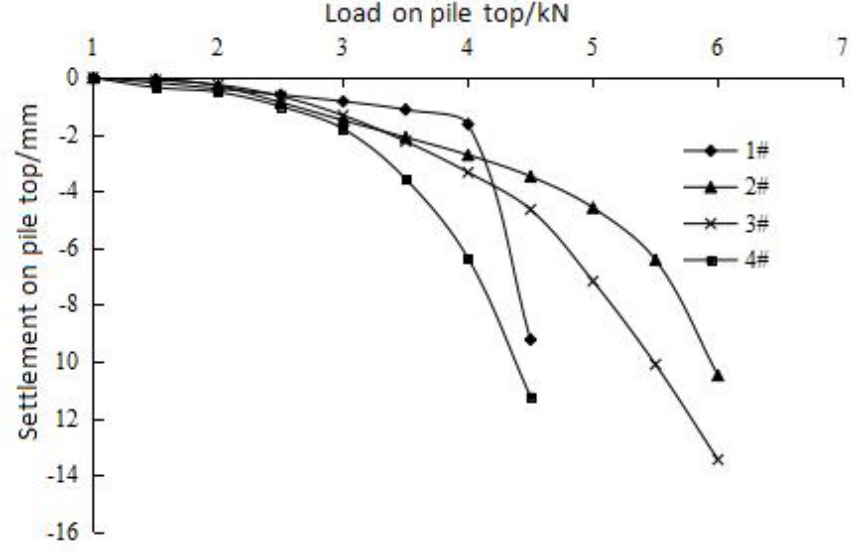

(a)

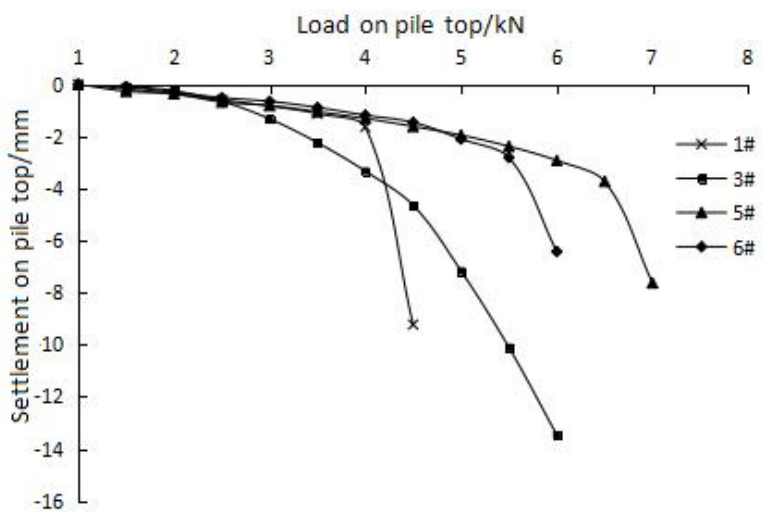

(b)

Fig.5 Load - Settlement Curve on Pile Top 


\section{Summary}

(1) Soil laternal displacement can normal lead to soil and pile raise and sink. the soil around pile is mainly compacted or plastic flow around piles in the process of soil lateral migration.Futhermore , soil laternal displacement will affect the bearing capacity of pile .

(2) The effect of the soil lateral displacement is the most significant on the position of 2 times pile diameter.The vertical bearing capacity of the pile can been increased by effect of soil compaction, and the pile settlement can been decreased by the plastic flow around the pile.

(3) Relationship of load-settlement will been affected by soil laternal displacement,the load position and distance have also effect on the bearing characteristic of passive pile.

\section{Acknowledgements}

This work is financially supported by hunan province natural science foundation of china(project No. 2016JJ2046)

\section{References}

[1]De Beer E E.The effects of horizontal loads on piles due to surcharge or seismic effects[A].Proc 9th ICSMFE[C], Tokyo, 1977: 347-558.

[2]Stewart D P.Lateral loading of piled bridge abutments due to embankment construction[D].Crawley,Australia:University of Western Australia, 1992.

[3]Stewart D P, Jewell R J \& Randolph M F. Design of pile bridge abutments on soft clay for loading from lateral soil movement[J].Geotechnique, 1994,44(2):277-296.

[4]Frank C, Boostra G C. Horizontal Pressure on Pile Foundations[A].In: proc.2nd ICSM FE[C]. Rotterdam, 1948, (4):131-135.

[5]Terzaghi K. Theoretical Soil Mechanics [M]. New York:John Wiley and sons, 1943.

[6]Li Z C, Yang M.Passive arching-active wedge modle of soil pressure calculation in passive piles[J]. Chinese Journal of Rock Mechanics and Engineering, ,2006,25（s2）:4241-4247. 